\title{
PENINGKATAN PRODUKTIVITAS TERNAK SAPI POTONG MELALUI PENERAPAN TEKNOLOGI PENGAWETAN PAKAN (SILASE KOMPLIT)
}

\author{
Paulus Klau Tahuk ${ }^{1)^{*}}$ dan Gerson Frans Bira ${ }^{2)}$ \\ ${ }^{1.2)}$ Program Studi Peternakan, Fakultas Pertanian, Universitas Timor, Indonesia ${ }^{1,2)}$ \\ Pos-el : Paulklau@ yahoo.co.id ${ }^{1}$, gersonbira@yahoo.co.id $^{2)}$ \\ *Corresponding author
}

\begin{abstract}
Abstrak
Tujuan dari kegiatan pengabdian ini adalah meningkatkan pengetahuan dan keterampilan Kelompok tani Nek'Mese Desa Usapinonot, Kecamatan Insana Barat, Kabupaten Timor Tengah Utara tentang teknologi silase komplit. Metode yang digunakan adalah FGD (focus disscussion group) dan praktek secara langsung tentang pembuatan silase komplit. Sebelum dan sesudah kegiatan pelatihan, anggota kelompok diberikan beberapa pertanyaan terkait silase komplit lewat kuesioner. Kegiatan berlangsung selama \pm 45 hari dimulai dari persiapan alat dan bahan sampai pada penilaian kualitas (fisik dan kimia) serta penilaian tingkat palatabilitas ternak sapi potong terhadap silase komplit yang dibuat. Bahan pembuatan silase adalah gamal (40\%), lamtoro (30\%), dedak padi (15\%), tepung jagung (10\%) dan gula (5\%). Silase komplit yang didapat diuji kualitas fisik berupa warna, tekstur, aroma dan $\mathrm{pH}$, kualitas fisik dilakukan dengan analisis proksimat dan palatabilitas ternak dilihat dengan memberikan beberapa pilihan pakan pada sapi penggemukan. Hasil yang didapat adalah warna silase hijau kekuningan, wangi asam laktat, bertekstur padat $\mathrm{pH} 3,50$. Sedangkan kandungan silase komplit, BK (92\%), BO (82,2\%), PK (10,8\%), LK (7,28\%), BETN (49,12\%) serta EM $(2713,87 \mathrm{Kkal} / \mathrm{kg})$ serta memiliki nilai palatabilitas yang tergolong tinggi. Tingkat pengetahuan dan pemahaman anggota kelompok tani meningkat $98 \%$. Tingkat capaian dari kegiatan pengabdian ini adalah $100 \%$.
\end{abstract}

Kata Kunci : Kualitas, Silase, Palatabilitas, Tingkat Pengetahuan.

\begin{abstract}
The purpose of this service activity is to increase the knowledge and skills of the Nek'Mese Farmers Group in Usapinonot Village, Insana Barat District, Timor Tengah Utara about complete silage technology. The method used is FGD (focus disscussion group) and practice directly about complete silage making. Before and after the training activities, group members were given several questions related to complete silage through the questionnaire. The activity lasts for \pm 45 days starting from the preparation of tools and materials to the assessment of quality (physical and chemical) and the assessment of the level of palatability of beef cattle to complete silage made. Silage-making materials are gamal (40\%), lamtoro (30\%), rice bran (15\%), corn flour (10\%) and sugar (5\%). Complete silage obtained was tested for physical quality in the form of color, texture, flavour and $\mathrm{pH}$, physical quality was carried out by proximate analysis and palatability of livestock seen by providing several feed choices in fattening cattle. The results obtained are the color of yellowish green silage, fragrant lactic acid, solid textured $\mathrm{pH} 3.50$. While the complete silage content, BK (92\%), BO (82.2\%), PK (10.8\%), LK (7.28\%), BETN (49.12\%) and EM (2713.87 Kcal/kg) and has a high palatability value. The level of knowledge and understanding of farmer group members increased $98 \%$. The level of achievement of this service activity is $100 \%$.
\end{abstract}

Keywords: Quality, Silage, Palatability, Knowledge Level 


\section{PENDAHULUAN}

Pakan merupakan salah satu faktor terbesar dalam menunjang dan meningkatkan produktivitas ternak. Hal ini dikarenakan $60-70 \%$ biaya pemeliharaan ternak yang dikeluarkan oleh petani/peternak untuk meningkatkan produksi ternak berasal dari pakan.

Kelompok tani Nek'Mese merupakan salah satu kelompok yang terletak di Desa Usapinonot, Kecamatan Insana Barat, Kabupaten Timor Tengah Utara (TTU). Sejak pembentukannya, kelompok tani ini bergerak dalam bidang peternakan khususnya penggemukan dan pembibitan ternak sapi potong. Selain itu, anggota kelompok Tani Nek'mese juga bergerak dalam bidang pertanian tanaman pangan untuk memenuhi kebutuhan keluarga.

Dalam mengelola usaha penggemukan ternaknya, masalah umum yang dihadapi setiap tahun oleh petani/peternak adalah ketersediaan pakan. Dimana secara umum kondisi ketersediaan pakan di padang penggembalaan alam di NTT, khususnya Timor Tengah Utara cukup melimpah pada musim penghujan; dan sebaliknya pada musim kemarau ketersediaan pakan pada musim kemarau sangat minim di daerah lahan kering. Akibatnya, pada musim hujan ternak yang dipelihara oleh petani/peternak menunjukkan kinerja pertumbuhan yang lebih tinggi bila dibandingkan dengan musim kemarau.

Menurut laporan Tahuk et al. (2018), kinerja pertumbuhan Sapi Bali jantan yang digemukkan oleh petani/peternakan di Kelompok Tani Nek'mese berbeda antara musim hujan dan musim kemarau. Pada musim hujan, PBBH ternak mencapai 0,51 kg/ekor/hari, sebaliknya pada musim kemarau PBBH menurun menjadi 0,30 kg/ekor/hari.

Melihat kondisi di atas, maka permasalahan kekurangan pakan ini perlu dicarikan jalan keluarnya sehingga produktivitas ternak yang digemukkan oleh petani/peternak tetap optimal sepanjang tahun. Salah satu alternatif yang ditempuh adalah memanfaatkan kelebihan pakan pada musim hujan sebagai lumbung pakan pada musim kemarau. Hal ini dapat dilakukan dengan mengembangkan teknologi tepat guna seperti pembuatan silase komplit.

Silase komplit merupakan salah satu teknik pengawetan pakan atau hijauan atau limbah pertanian yang telah dicampur dengan sumber karbohidrat mudah tercerna pada kadar air tertentu melalui proses fermentasi mikrobial oleh bakteri yang berlangsung di dalam tempat yang disebut silo (McDonald et al. 2002). Pada proses pembentukan silase komplit, karbohidrat mudah larut dikonversi menjadi asam laktat oleh bakteri. Akibatnya, terjadi penurunan $\mathrm{pH}$ menjadi 4,2, atau lebih rendah sehingga pertumbuhan mikroba patogen menjadi terhambat. Dengan demikian, bahan pakan yang diawetkan dalam silo tetap terjaga kualitasnya untuk dimanfaatkan oleh ternak.

Menurut Utomo (2004), faktor penting dalam menentukan keberhasilan pembuatan silase adalah penambahan bahan aditif untuk mempercepat proses ensilase sehingga tercapainya kondisi optimum silase Diharapkan dengan penambahan aditif ini kondisi optimum silase dapat tercapai dan juga terjadi peningkatan kualitas nutrisi dari silase tersebut.

\section{METODE}

Kegiatan pengabdian berlangsung di Kelompok Tani Nek'Mese, Desa Usapinonot, Kecamatan Insana Barat, Kabupaten Timor Tengah Utara (TTU) pada bulan Juli sampai Agustus 2018. Adapun alat-alat yang digunakan dalam pembuatan silase komplit ini terdiri dari : drum plastik dengan kapasitas $150 \mathrm{~kg}$, terpal, $\mathrm{pH}$ digital, alat potong. Selain itu 
kuesioner dan alat tulis menulis untuk menggali informasi dari mitra (kelompok tani) terkait informasi pembuatan silase komplit dan penerapannya. Bahan-bahan yang digunakan adalah : hijauan gamal dan lamtoro, dedak padi, tepung jagung, gula pasir. Untuk menguji dan menilai tingkat palatabilitas silase komplit yang diproduksi, digunakan 5 ekor ternak sapi Bali penggemukan untuk uji coba atau aplikasinya. Metode yang digunakan dalam kegiatan pengabdian ini adalah FGD (focus disscussion group) terkait dengan tahapan dan prosedurprosdur pembuatan silase komplit. Langkah awal dari proses pembuatan silase komplit ini adalah penyampaian materi melalui penyuluhan oleh tim pelaksana terkait konsep dan prinsip-prinsip pembuatan silase komplit.

Adapun tahapan-tahapan dari kegiatan pengabdian dapat dilihat pada skema dibawah ini :

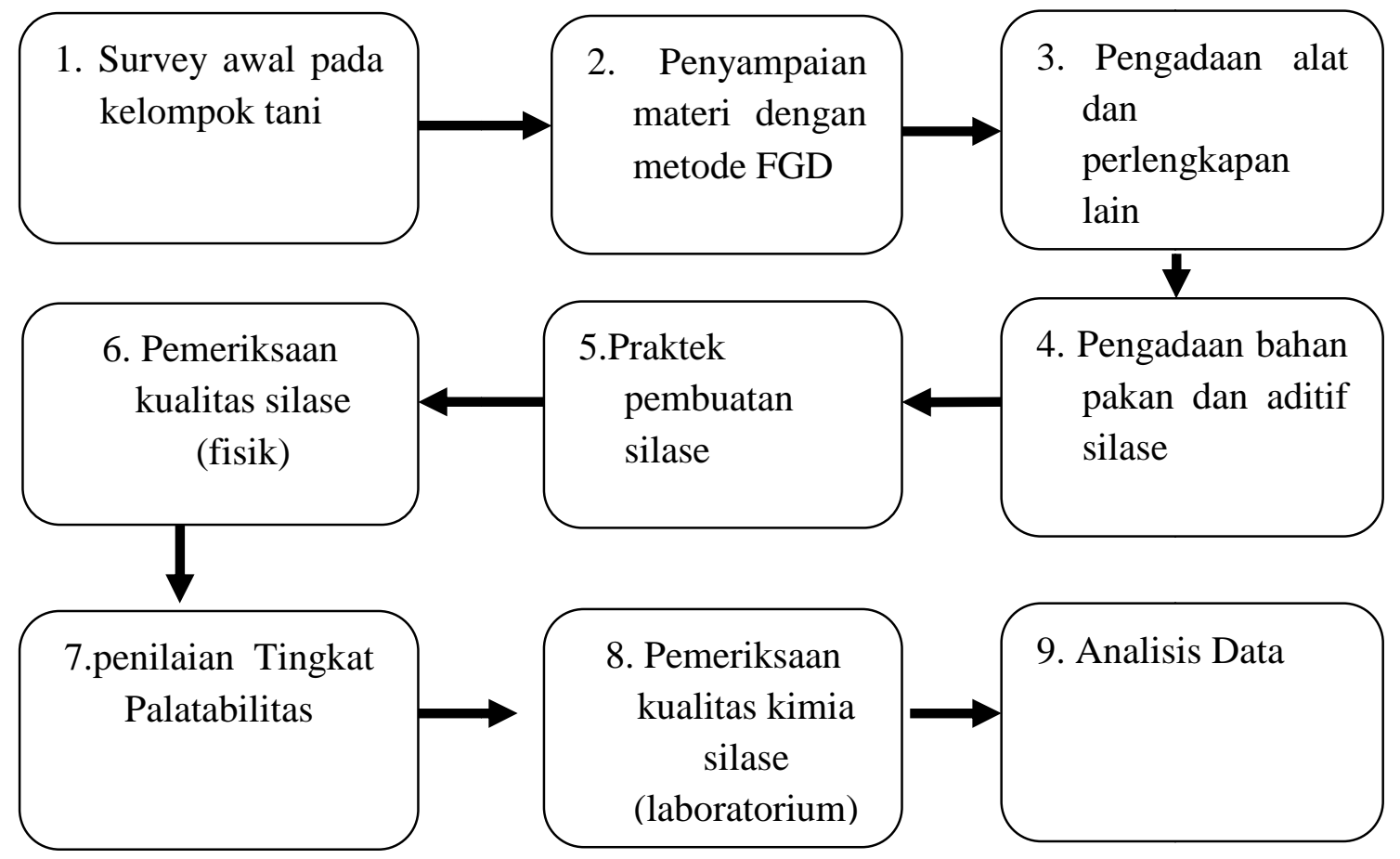

Tim pengabdian terus mendampingi serta melakukan monitoring hingga kelompok tani terampil, mahir dan mandiri dalam teknologi pengawetan pakan melalui pembuatan silase komplit. Untuk menggali informasi terkait kemampuan kelompok tani dalam pembuatan silase komplit, peserta pelatihan diwawancarai dengan menggunakan kuesioner yang telah tersedia Informasi yang digali mencakup daya terima dan pemahaman terhadap pelatihan dan teknologi silase komplit.

Tahapan akhir dari pembuatan silase komplit setelah fermentasi selama 21 dari didalam silo adalah pengujian kualitas fisik, serta uji palatabilitas pada ternak. Pada tahap ini, silo dibuka dan diuji kualitas fisik, diangin-anginkan, kemudian diujicobakan pada sapi bali yang gemukkan di kelompok tani. Selain itu, dilakukan analisis proksimat terhadap silase komplit untuk mengetahui kandungan nutrisinya. 


\section{HASIL DAN PEMBAHASAN \\ Bahan, Proses dan Kriteria Silase Komplit}

Bahan dan Peralatan. Bahan-bahan yang digunakan dalam pembuatan silase komplit merupakan bahan-bahan yang ketersediannya melimpah di Desa Usapinonot, bahan-bahan tersebut terdiri dari 1).Gamal (Gliricidia Sepium); ketersediaan gamal cukup melimpah di daerah-daerah tropis dan mampu tumbuh pada daerah marginal, tergolong leguminosa pohon yang mempunyai kandungan nutrisi seperti BK 35,67\%, PK 20-30\%, SK 15\%. 2).Lamtoro (leucaena leucocephala); sama halnya dengan gamal, lamtoro tergolong dalam leguminosa pohon yang PK nya berkisar 25-32\%. Dedak padi ; dedak padi merupakan hasil samping dari penggilingan padi yang mengandung BK 89,6\%, PK 15,9\%, SK 8,5\%. 3).Jagung ; Jagung merupakan butiran yang mempunyai total nutrien tercerna (TDN) dan net energi (NE) yang tinggi, memiliki PK 10,8\%, SK 3,1\%. 4).Gula; gula merupakan senyawa organik yang penting sebagai sumber kalori karena mudah dicerna didalam tubuh dan mempunyai rasa manis. Gula (kristalisasi sari tebu) mempunyai bentuk, aroma dan fungsi yang berbeda. Dalam kegiatan pengabdian ini, gula yang dipakai adalah gula pasir berbutir kasar.

Prosedur pembuatan silase komplit. Adapun prosedur pembuatan silase komplit adalah : hijauan (gamal dan lamtoro) dipotong dan diangin-anginkan selama 3 jam untuk menurunkan kadar air, kemudian dicacah dengan ukuran 3-5 cm yang dapat memudahkan dalam pencampuran dan pengisian dalam silo. Cacahan tersebut ditimbang sesuai dengan persentasenya, masing-masing hijauan $70 \%$ dan aditif $30 \%$. Setelah mendapat persentasenya masing-masing, cacahan hijauan dan aditif dicampur hingga merata dan dimasukkan ke dalam drum plastik (silo) sedikit demi sedikit sambil ditekan agar dapat mengeluarkan oksigen sebanyak mungkin (prinsip fermentase). Silo ditutup dan disimpan selama 21 dalam ruangan agar terhindar dari paparan cahaya matahari secara langsung sehingga proses fermentasi berjalan sempurna.

Setelah 21 hari, silo dibuka untuk dilakukan penilaian terhadap kualitas silase komplit secara fisik dan kimia. Secara fisik hal yang diamati dan diukur adalah $\mathrm{pH}$, warna, terkstur dan aroma. Pengukuran $\mathrm{pH}$ silase komplit menggunakan $\mathrm{pH}$ digital dengan prosedur sebagai berikut : pH meter pertama dikalibrasi menggunakan larutan buffer ber $\mathrm{pH} 2$ dan 6 (Hasil kalibrasi tersebut dimaksudkan untuk mendapat nilai $\mathrm{pH}$ yang dengan tingkat keakurasian yang benar dan tepat. Selanjutntya, $\mathrm{pH}$ meter dimasukkan ke dalam silase komplit yang telah jadi. $\mathrm{pH}$ meter akan menunjukkan nilai $\mathrm{pH}$ dengan keakurasian yang tepat.

Penilaian kualitas fisik meliputi warna, tekstur, dan aroma dilakukan oleh panelis yang terdiri dari tim pengabdian dan anggota kelompok. Dalam penilaian skor yang diberikan berkisar 1-3, dengan keterangan sebagai berikut :

a. Warna (skor 1-3)

3. Hijau alami atau hijau kekuningan

2. Hijau gelap atau kuning kecoklatan

1. Coklat sampai hitam

b. Aroma (skor 1-3)

3. Asam (tetap segar)

2. Tidak asam atau tidak busuk

1. Busuk 
c. Tekstur (skor 1-3)

3. Padat

2. Agak lembek

1. Lembek

d. $\mathrm{pH}$ silase

3,0-4,2 Baik sekali

4,2-4,5 Baik

4,5-4,8 Sedang

Setelah pemeriksaan fisik, diambil cuplikan sampel untuk kemudian dibawah ke laboratorium untuk dilakukan analisis proksimat (BK, BO, PK, LK, SK, BETN, CHO, EM).

\section{Kualitas Fisik Silase Komplit}

Silase adalah pakan yang telah diawetkan yang diproses dari bahan baku yang berupa tanaman hijauan dengan jumlah kadar atau kandungan air pada tingkat tertentu kemudian dimasukkan dalam sebuah tempat yang tertutup rapat kedap udara, yang biasa disebut dengan silo selama kurang lebih tiga minggu (Hadju, 2014). Didalam silo tersebut akan terjadi beberapa proses anaerob, dimana bakteri asam laktat akan mengkonsumsi zat gula yang terdapat pada bahan baku, sehingga terjadi proses fermentasi. Silase yang terbentuk karena proses fermentasi ini dapat disimpan untuk jangka waktu yang lama tanpa banyak mengurangi kandungan nutrisi dari bahan bakunya.

Dalam pembuatan silase komplit salah satu bahan yang perlu ditambahkan adalah aditif pakan. Bahan aditif tersebut berfungsi untuk mempercepat pembentukan asam laktat dan mencegah fermentasi berlebihan, mempercepat penurunan $\mathrm{pH}$, suplemen untuk zat makanan yang defisiensi dari hijauan yang digunakan. Kandungan nutrisi yang berbeda dari zat aditif yang digunakan dan taraf yang berbeda diduga akan menghasilkan kenaikan ataupun penurunan kandungan nutrisi dari silase itu sendiri. Hasil pengamatan terhadap kualitas fisik silase komplit dapat dilihat pada Tabel 1.

Tabel 1. Hasil Pengamatan Kualitas Fisik Silase Komplit

\begin{tabular}{|c|c|}
\hline Pengamatan & Nilai dan Skor \\
\hline Warna & Hijau kecoklatan/3 \\
\hline Tekstur & Padat $/ 3$ \\
\hline Aroma & Asam $/ 3$ \\
\hline $\mathrm{pH}$ & 3,50 baik sekali \\
\hline
\end{tabular}

Setelah proses ensilase selama 21 hari, tim pengabdian dan semua anggota kelompok tani bersama-sama membuka silo untuk melihat dan menilai karakteristik fisik dari silase komplit. Dari Tabel 1 dapat dilihat bahwa karakteristik fisik dari silase komplit yang diberi skor 1-3 tergolong tinggi. warna silase hijau kecoklatan dengan skor 3, bertekstur padat dengan skor 3, beraroma asam dengan skor 3 dan $\mathrm{pH}$ 3,50 atau dikategorikan baik sekali. Dapat dikatakan bahwa proses pembuatan silase komplit berjalan dengan efektif dan normal. Menurut Utomo (2004), karakteristik silase yang baik adalah warna silase : silase yang baik umumnya berwarna hijau kekuningan atau kecoklatan sedangkan warna yang kurang baik adalah coklat tua dan kehitaman, aroma : aroma silase agak asam atau tidak tajam bebas dari aroma manis, aroma amonia dan aroma $\mathrm{H} 2 \mathrm{~S}$, tekstur : kelihatan tetap dan masih jelas, tidak menggumpal, tidak lembek dan tidak berlendir. Selain itu, derajat keasaman menjadi faktor 
penting yang perlu menjadi perhatian. Silase dianggap memiliki kualitas silase yang baik bila mempunyai $\mathrm{pH} 4,5$ atau lebih rendah dan bebas dari jamur (Utomo, 2004).

Pembuatan silase komplit memiliki dampak positif karena kelompok tani telah mendapat solusi terkait upaya penyediaan pakan pada ternak selama musim kemarau yang berkepanjangan. Hal penting dalam pembuatan silase adalah penggunaan bahan aditif. Bahan aditif digunakan untuk meningkatkan kandungan nutrisi ataupun karbohidrat dalam pakan yang perannya untuk memenuhi kebutuhan nutrisi ternak. Kandungan nutrisi yang berbeda dari zat aditif yang digunakan diduga akan menghasilkan kenaikan ataupun penurunan kandungan nutrisi dari silase itu sendiri (Utomo et al., 2016).

Keberhasilan proses ensilase sangat tergantung pada cepat atau lambatnya pencapaian kondisi stabil pada bahan pakan pembuat silase. Dimana kestabilan kondisi ini sangat tergantung pada banyaknya oksigen dalam silo dan ketersediaan karbohidrat mudah larut dalam bahan pakan. Dalam kegiatan pengabdian ini dapat dikatakan optimal dengan proses pembuatan yang meminimalisir oksigen dalam silo (anaerob), penggunaan bahan aditif sebagai sumber karbohidrat mudah larut serta pencampuran bahan yang merata.

\section{Kualitas Kimia Silase Komplit}

Kualitas suatu pakan dapat ditentukan melalui pendekatan analisis proksimat di laboratorium dengan mengukur komposisi kimia dari pakan tersebut. Komposisi kimia yang menentukan kualitas pakan meliputi protein kasarnya (PK), bahan kering (BK)/organik (BO) dan kandungan serat kasar (SK), lemak, kalsium (Ca) dan phospor (P). Disamping itu juga ditentukan komponen-komponen lain yang terdapat dalam pakan tersebut yang kemungkinan dapat menimbulkan keracunan pada ternak yang mengkonsumsinya (Soejono, 1991)

Hasil pengujian laboratorium terhadap kandungan nutrisi silase komplit menunjukkan bahwa kandungan BK 92,00 \%, BO 82,22\%, PK 10,84\%, LK 7,28\%, SK 14,96\%, CHO $64,09 \%$, BETN 49,12\% dan EM 2713,86 Kkal/kg. Kandungan nutrisi yang didapat ini dapat memenuhi kebutuhan ternak untuk berproduksi.

Hasil yang diperoleh ini tergolong tinggi jika dibandingkan dengan laporan Muwakhid (2010) yang menggunakan inokulum bakteri asam laktat berbeda yang hanya memperoleh BK 35,12-37,91\%, BO 84,26-84,93\% serta PK 6,85-7,40\%. Hal ini dikarenakan perbedaan bahan pakan yang digunakan pembuatan silase, dan juga beberapa aditif yang digunakan dalam kegiatan pengabdian ini memiliki kandungan protein dan karbohidrat cukup tinggi.

\section{Respon ternak terhadap silase komplit}

Respon ternak terhadap silase komplit yang dibuat merupakan hal penting untuk melihat daya tarik atau tingkat kesukaan ternak terhadap pakan. Palatabilitas merupakan salah satu faktor penting untuk melihat konsumsi ternak yang pada umumnya dipengaruhi oleh aroma, rasa, warna serta tekstur pakan. Menurut Kartadisastra (1997), keadaan fisik dan kimiawi pakan yang dicerminkan dari kenampakan, aroma, rasa, dan tekstur dapat menggambarkan daya tarik sehingga dapat merangsang ternak untuk mengkonsumsinya. Jika dilihat pada Tabel 1, maka tekstur, aroma dan warna silase komplit yang dihasilkan dalam kegiatan pengabdian ini dapat meningkatkan palatabilitas ternak khusunya ternak sapi.

Uji palatabilitas dalam kegiatan pengabdian ini dilakukan setelah dilakukannya uji kualitas fisik silase komplit. Ternak sapi penggemukan yang diuji palatabilitasnya adalah berjumlah 5 ekor. Hasil pengamatan menunjukkan bahwa daya terima ternak sapi terhadap silase komplit yang diberikan cukup tinggi. Hal ini terlihat dari aktivitas ternak yang 
langsung mengkonsumsi silase komplit tanpa melalui fase adaptasi. Cukup tingginya daya terima ternak terhadap silase komplit ini menjadi faktor pendorong agar teknologi pengawetan pakan ini dapat diterapkan oleh petani/peternak dalam menggemukan ternaknya.

Palatabilitas ternak yang tinggi diduga karena tekstur silase yang padat, aroma khas (asam laktat) yang dapat mempengaruhi konsumsi serta sangat disukai ternak dan warna hijau kecoklatan yang umumnya dikonsumsi oleh ternak ruminansia. Konsumsi pakan pada umumnya dipengaruhi oleh rasa dan aroma pakan. Silase komplit (hijauan dan aditif) yang tercampur merata mengakibatkan warna dan aroma lebih menarik serta ternak tidak dapat memilah dan memilih pakan akibatnya konsumsi ternak akan meningkat.

\section{Tingkat Pemahaman Anggota Kelompok Tani}

Tingkat pemahaman dan pengetahuan masyarakat khususnya kelompok tani Nek'Mese dapat dilihat dari kuesioner yang diberikan sebelum dan sesudah kegiatan. Antusias anggota kelompok tergolong tinggi dalam kegiatan ini yang dapat dilihat dari tingkat kehadirannya (partisipasi). Dari total 61 anggota yang terdiri dari kelompok tani laki-laki (30 orang) dan kelompok tani wanita (31 orang) yang hadir dalam kegiatan berjumlah 33 orang atau $55 \%$.

Berdasarkan kuesioner, pada umumnya anggota kelompok Tani Nek'mese adalah peternak $(96,96 \%)$. Tingkat pendidikan anggota kelompok adalah tidak bersekolah adalah $6,06 \%$, tamat SD 84,84\%, dan tamat SLTA 9,09\%. Hal ini membuktikan bahwa tingkat pendidikan anggota kelompok sangat rendah sehingga daya terima terhadap ilmu pengetahuan dan teknologi yang baru perlu untuk dilakukan secara bertahap dan terus menerus.

Sedikitnya 24,24\% anggota kelompok sudah pernah mengikuti kegiatan pelatihan pembuatan silase namun silase yang diperkenalkan masih dalam silase tunggal; sedangkan pembuatan silase komplit merupakan pengetahuan baru yang perlu dipelajari untuk dapat diaplikasikan. Penilaian awal (pre test) terdahap peserta kegiatan menunjukkan bahwa tingkat pemahaman peternak rata-rata adalah $75 \%$. Hal ini menunjukkan bahwa anggota kelompok masih memiliki pemahaman rendah sampai sedang tentang pembuatan silase komplit. Setelah dilakukannya pelatihan dengan menggunakan FGD dan praktek secara langsung tingkat pemahaman anggota kelompok tentang silase komplit meningkat dengan nilai ratarata 98\%. Hal ini menggambarkan bahwa kegiatan pelatihan pembuatan silase komplit dalam program pengabdian ini berkontribusi positif dalam meningkatkan pengetahuan peternak.

\section{SIMPULAN}

Kegiatan pengabdian penerapan teknologi pengawetan pakan (silase komplit) di Kelompok Tani Nek'Mese Desa Usapinonot Kecamatan Insana Barat Kabupaten TTU, telah dilaksanakan dengan baik tanpa adanya halangan yang berarti. Partispasi peternak dalam pembuatan silase komplit cukup tinggi dengan tingkat pemahaman mencapai $98 \%$.

Berdasarkan kualitas fisiknya, silase komplit yang dihasilkan memenuhi kriteria silase yang baik dengan warna hijau kecoklatan, bertekstur padar, beraroma asam dan memiliki $\mathrm{pH}$ 3,50. Komposisi kimia silase komplit yang dihasilkan cukup baik dengan bahan kering $92,00 \%$, bahan organik 82,22\%, protein kasar 10,84\%, lemak kasar 7,28\%, serat kasar 14,96\%, CHO 64,09\%, BETN 49,12\% dan EM 2713,86 Kkal/kg. Kualitas silase komplit yang tergolong tinggi ini memberi dampak pada tingkat palatabilitas yang tinggi pula. 


\section{UCAPAN TERIMA KASIH}

Ucapan terima kasih diberikan bagi LPPM Universitas Timor sebagai penyandang dana dalam kegiatan pengabdian pada masyarakat sehingga telah berjalan dengan baik, serta kelompok tani Nek'mese Desa Usapinonot yang telah menerima tim sebagai mitra dalam memajukan produksi peternakan.

\section{DAFTAR PUSTAKA}

Hadju, L. 2014. Membuat Silase. Balai Pelatihan Pertanian-Jambi

Kartadisastra, H.R. 1997. Penyediaan dan Pengelolaan Pakan Ternak Ruminansia. Kanisius. Yogyakarta

McDonald P, Edwards RA, Greenhalgh JFD, Morgan CA. 2002. Animal Nutrition. 6th Ed. Harlow (GB): Pearson Education.

Muwakhid, B. 2010. Kualitas Silase Hijauan Gembilina (Gmelina arborea) Yang Dibuat Menggunakan Inokulum Bakteri Asam Laktat Berbeda. Seminar Nasional Teknologi Peternakan dan Veteriner 2010.

Soejono, M. 1991. Analisis Evaluasi. Pusat University Bioteknologi, Universitas Gadjah Mada.

Tahuk, P.K., E. Baliarti, S.P.S Budhi, Panjono. 2018. The Effect of Season on the Feed Quantity and Quality and Growth Performance of Male Bali Cattle Fattened in Smallholder Farms. Buletin Peternakan (Bulletin of Animal Science). 42 (3): 203209.

Utomo, R., C.T.Noviandi, A.Astuti, N. Umami, L.J.M.C. kale Lado, A.B. Pratama, N.A. Jamil, N. Sugiyanto. 2016. Pengaruh Penggunaan Aditif Pada Kualitas Silase Hijauan Sorghum Vulgare. Prosiding Simposium Nasional Penelitian dan Pengembangan Peternakan Tropik Tahun 2016-UGM,Yogyakarta. 